\title{
Two Stage Approach for Microbial Oil Production using Yarrowia lipolytica NCIM 3590
}

\author{
Warke MA, Pawar PP, Kothari SD, Odaneth AA* and Lali AM \\ DBT-ICT Centre for Energy Biosciences, Institute of Chemical Technology, India
}

Submission: June 12, 2017; Published: July 28, 2017

*Corresponding author: Odaneth AA, DBT-ICT Centre for Energy Biosciences, Institute of Chemical Technology, Nathalal Parikh Marg, Mumbai-19, India, Fax: +91-22-24145614; Tel: +91-22-33612312; Email: a.dbtceb@gmail.com

Abstract

Oil production in Yarrowia lipolytica NCIM 3590 has been studied using a single and two-stage culture system. In two stage, the culture was initially grown in nitrogen enriched conditions followed by oil production in carbonaceous medium. Maximum oil production (37.5\% of yeast [dry weight]) was obtained with higher sugar concentrations in two stages as compared to a single stage system (viz. $21.2 \%$ of yeast dry weight). The oil titers also increased to $4.8 \mathrm{~g} / \mathrm{L}$ in two-stage system. Thus, a two-stage fermentation system proves to be advantageous in comparison to a single-stage. The oil produced was majorly triglyceride in nature with free fatty acid content $<5 \%$.

Keywords: Yarrowia lipolytica; Microbial oil; Two-stage fermentation

Abbreviations: TAG: Triacylglycerol; MAG: Monoacylglycerol; DAG: Diacylglycerol; FAME: Fatty Acid Methyl Ester; ELSD: Evaporative Light Scattering Detector; Exlip: Extracellular Lipid; Inlip: Intracellular Lipid; Surflip: Surface Bound Lipid; MGYP: Malt Extract Glucose Yeast Extract Peptone

\section{Introduction}

Paucity of food and energy resources has demanded for an alternate renewable resource to suffice the needs of the increasing population. However, the energy obtained from fossil fuels, oil crops etc. cannot realistically satisfy even a small fraction of the existing demand. Therefore, the exploration of renewable energy resources which do not compete with arable land has become a necessity. Microbial oil provides as a promising noncrop based renewable resource; catering as a source of highly nutritious lipids, majorly in the form of triglycerides, which can further be used as a source of food as well as an energy resource [1].

Oleaginous organisms including bacteria, yeasts, algae, and fungi have the ability to convert carbon rich substrates into lipids and accumulate them at the levels $>20 \%$ of the dry cell weight (DCW) [2-4]. Yeast species, such as Rhodosporidium sp., Rhodotorula sp., Lipomyces sp., and Yarrowia lipolytica, are the ones whose intracellular lipid levels can reach $70 \%$ of DCW [1]. Noticeably, some of these oleaginous microorganisms can accumulate lipids faster with the fatty acid composition similar to that of crop oils, and have several advantages over crop oils such as a short life cycle, no needs for farmland and are independent to seasonal and climatic variations [5,6]. In the process of microbial oil accumulation, the complete conversion and utilization of carbon substrate is a major issue. Hence, microbial oil production has received significant attention as a potential precursor for production of biofuels, oleo- chemicals and food products [7]. Oleaginous yeasts specifically prove to be more beneficial as they have the potential to convert various carbon sources, ranging from sugars or agro-industrial waste hydrolysates to other alternate carbon suppliers like glycerol, which is produced in large amounts along with Biodiesel.

$Y$. lipolytica is used as a model organism for bio lipid production due to its unique characteristics to metabolize substrates such as alkanes, fatty acids and lipids and its ability to accumulate high levels of lipids. In addition, it has been studied for industrial and environmental applications to produce vast range of valuable bio products. This non-conventional yeast is regarded as non-pathogenic and categorized as GRAS (generally recognized as safe) by the Food and Drug Administration [8].

In recent years, much effort has been focused on directing carbon flux towards lipid synthesis either through optimizations of the cultivation process or biotechnological approaches such 
as genetic engineering, metabolic engineering, and synthetic biology. The carbon flux is directed toward lipid synthesis through optimizations of the cultivation process, mostly by limiting nitrogen (through the manipulation of a high $\mathrm{C} / \mathrm{N}$ ratio), which increases production of precursors for fatty acid synthesis. However, under such circumstances, lipid accumulation is achieved at the expense of limited cell proliferations; precise control of nutrients is thus essential to fine balance both the requirements of cell proliferation and lipid accumulation [2]. For this purpose, optimization in cultivations which allows high density fermentation with satisfied lipid content has been well researched [9].

Yarrowia in their late stages of growth tend to divert their pathways towards lipid accumulation and metabolite production in depleted nitrogen conditions. Single stage fermentation systems with lower nitrogen content focused more on oil yields therefore suffer from lower cell mass and low final titres of oil in the fermentation broth. It was therefore thought that the separating the oil production phase from the cell growth phase, would prove to be beneficial in increasing the oil titers. A twostage culture system can be used where in the first stage the cells are allowed to achieve high cell density cultivation of oleaginous yeast cells, by using nitrogen enriched medium and in the second stage, lipid accumulation can be initiated in nitrogen limited medium [10].

\section{Materials and Methods}

\section{Strain and chemicals}

The oleaginous yeast strain of Yarrowia lipolytica NCIM 3590 was procured from National Collection of Industrial Microorganisms (NCIM)-National Chemical Laboratory, Pune, India. Stock of yeast strain was maintained at $-80{ }^{\circ} \mathrm{C}$ in $40 \%$ $(\mathrm{v} / \mathrm{v})$ glycerol. The culture was revived in $50 \mathrm{~mL}$ MGYP medium containing 3g/L Malt extract, $20 \mathrm{~g} / \mathrm{L}$ Glucose, $3 \mathrm{~g} / \mathrm{L}$ Yeast extract and $5 \mathrm{~g} / \mathrm{L}$ Peptone and was incubated at $28^{\circ} \mathrm{C}$ for $48 \mathrm{~h}$. This culture was later used as pre-inoculum for further experimentation. The Media components like Malt extract, Yeast extract, Peptone and glucose were obtained from HiMedia, India.

\section{Production of microbial oil by oleaginous yeast in the growth media}

The experiment was performed in individual $250 \mathrm{~mL}$ Erlenmeyer flask containing $100 \mathrm{~mL}$ growth medium composed of MYP along with various carbon sources (viz. 2\% glucose, $2 \%$ xylose, $2 \%$ acetate and $2 \%$ succinate). The flasks were inoculated with the pre-inoculum culture to make a $10 \%(\mathrm{v} / \mathrm{v})$ inoculum concentration and incubated in a rotary shaker at $200 \mathrm{rpm}$ and $28^{\circ} \mathrm{C}$ for $72 \mathrm{hrs}$. Cells were harvested by centrifugation for oil extraction and estimation.

\section{Role of $\mathrm{C} / \mathrm{N}$ ratio in microbial oil production}

The cells were inoculated in different $250 \mathrm{~mL}$ Erlenmeyer flasks containing $100 \mathrm{~mL}$ growth medium with $\mathrm{C} / \mathrm{N}$ ratio ranging from 1.55 to 350 and were incubated in a rotary shaker at $200 \mathrm{rpm}$ and $28^{\circ} \mathrm{C}$ for $72 \mathrm{hrs}$.

\section{Production of microbial oil by oleaginous yeast using two stage approaches}

Yarrowia lipolytica NCIM 3590 cells were grown in growth medium and harvested by centrifugation, which were then washed with sterile distilled water and resuspended in oil production medium containing $100 \mathrm{~mL}$ sterile glucose solution with concentration ranging from 10 to $60 \mathrm{~g} / \mathrm{L}$. This was incubated in a shaker at $20{ }^{\circ} \mathrm{C}$ with an agitation of $200 \mathrm{rpm}$. After $72 \mathrm{hrs}$ of incubation, the microbial oil produced was extracted from the cells and the supernatant. The oil content was estimated gravimetrically and the yield was estimated.

\section{High cell density cultivation of oleaginous yeast cell biomass}

The cell biomass production of Yarrowia lipolytica NCIM 3590 was carried out in a 5 fermentor containing $1 \mathrm{~L}$ of MGYP media. Culturing was initially carried out in a batch mode, at 28 ${ }^{\circ} \mathrm{C}$, agitation of $200 \mathrm{rpm}$ and aeration of $1 \mathrm{vvm}$ for $48 \mathrm{hrs}$. Later, the fermentor was operated in a chemostat mode at different dilution rates with higher concentration of Nitrogenous auxiliaries (Yeast extract and Peptone with $10 \& 20 \mathrm{~g} / \mathrm{L}$ concentrations) and fermentable sugar (glucose $100 \mathrm{~g} / \mathrm{L}$ ). The media was replenished continuously and the cells were retained using the Hollow fiber membrane system.

\section{Extraction of oil and its estimation}

The oil production broth after $72 \mathrm{hrs}$ incubation at $20^{\circ} \mathrm{C}$ and $200 \mathrm{rpm}$ was centrifuged in a refrigerated centrifuge at 8000 rpm and $20^{\circ} \mathrm{C}$ for 15 minutes. Extraction of the microbial oil from the yeast cell biomass (obtained as a pellet) was carried out by using organic solvents like Propan-2-ol and chloroform (1:3) for cell disruption and oil extraction respectively. The extraction was carried out in a thermo-mixer at $50{ }^{\circ} \mathrm{C}$ and $800 \mathrm{rpm}$ for $1 \mathrm{hr}$. The extraction was repeated to ensure the complete removal of oil from the cells Yao et al. [11] The Extracellular oil was extracted from the supernatant, by liquid-liquid extraction using non-polar solvent like Chloroform. The total microbial oil thus obtained was, quantified gravimetrically after distillation of the solvent. Organic solvents used for extraction and analysis were of analytical grade or chromatographically pure and were obtained from SD Fine Chemicals Ltd., India.

\section{Analysis of the microbial oil}

Qualitative analysis of the microbial oil produced from Yarrowia lipolytica was done for the of different components like TAG, MAG, DAG and FFA in the oil. The Free Fatty acid content present in the oil was estimated by proximate titrimetric analysis with $\mathrm{KOH}$. The Fatty acid composition analysis was done by GC-MS. For GC analysis of the fatty acids, the hexane layer was evaporated using rotary vacuum distillation from an aliquot of sample, which was re-dissolved in $1 \mathrm{~mL}$ boron tri-fluoride and $5 \mathrm{~mL}$ methanol. 
The derivatization protocol was followed according to that optimized by Shantha et al. [12]. The sample with boron trifluoride and methanol was kept in reflux condition for $5 \mathrm{~min}$. The fatty acid methyl ester (FAME) was extracted in hexane and this hexane layer was given water washes to remove all watersoluble impurities. The hexane layer was dried using NaHSO4 and was analyzed on Agilent Technology 7890A GC equipped with 5975C MS system. Samples were analyzed on a HP5MS capillary column $(30 \mathrm{~m} \times 0.20 \mathrm{~mm}, 0.33 \mu \mathrm{m}$ coating thickness $)$. The oven temperature was maintained for $1 \mathrm{~min}$ at $70{ }^{\circ} \mathrm{C}$, then increased linearly to $240{ }^{\circ} \mathrm{C}$ at a rate of $7{ }^{\circ} \mathrm{C}$ Min-1 with helium as the carrier gas.

The HPLC-ELSD system with C-18, $15 \mathrm{~cm}$ column was developed for glyceride compositional analysis. Since, the analysis of TAG was of more interest (as Edible grade microbial oil should contain more of TAG than FFA), the samples were neutralized with $\mathrm{NaOH}$ so that the glycerides at lower retention times can be distinguished. The method with the flow rate of $1 \mathrm{ml} / \mathrm{min}$, time: $40 \mathrm{~min}$, temp $30{ }^{\circ} \mathrm{C}$, gain 4 and mobile phase (90\% $\mathrm{MeOH}$ and $100 \% \mathrm{DCM}$ ) was used for gradient elution of cluster of glycerides.

\section{Results and Discussion}

\section{Production of microbial oil by oleaginous yeast in the growth media}

Table 1: Growth associated oil production by Yarrowia lipolytica NCIM 3590 , The oil production in the growth phase with respect to Oil/ Lipid content wrt to dry cell biomass and oil yield based on glucose consumption is shown, DCW: Dry cell weight.

\begin{tabular}{|c|c|c|}
\hline $\begin{array}{c}\text { Carbon Source in } \\
\text { Growth Media }\end{array}$ & $\begin{array}{c}\text { Lipid Content Wrt } \\
\text { DCW of the Cell (\%) }\end{array}$ & $\begin{array}{c}\text { Oil Yield (oil g/g of } \\
\text { glucose) }\end{array}$ \\
\hline Glucose & $21.2 \%$ & 0.06 \\
\hline Xylose & $6.9 \%$ & 0.07 \\
\hline Acetate & $15.61 \%$ & 0.03 \\
\hline Succinate & $7.08 \%$ & 0.007 \\
\hline
\end{tabular}

Table 2: Different modes of fermenter operation, the increase in the cell biomass (Dry cell weight) with change in the mode of fermenter operation is shown, MGYP: Malt extract, Glucose, Yeast extract, Peptone; DCW: Dry cell weight.

\begin{tabular}{|c|c|c|c|}
\hline $\begin{array}{c}\text { Mode of } \\
\text { Operation }\end{array}$ & Batch Mode & Fed-batch & $\begin{array}{c}\text { Chemostat } \\
\text { with MGYP }\end{array}$ \\
\hline $\begin{array}{c}\text { Cell density } \\
\text { (DCW) in g }\end{array}$ & 1.6 & 1.8 & 32.2 \\
\hline
\end{tabular}

The oleaginous strain of Yarrowia lipolytica NCIM 3590, has been found to show substrate affinity to a wide range of carbon sources. These include sugars hexoses like glucose, pentose like xylose, arabinose etc., along with organic acids like citric acids, succinate, malate etc, sugar alcohols, and even glycerol. Yarrowia lipolytica NCIM 3590 grown on a synthetic media containing MGYP in a batch mode for $48 \mathrm{hrs}$, yielded cell density of $1.6 \mathrm{~g}$ DCW/L, with the growth associated oil content of $21.27 \%$ wrt to the DCW of the cell biomass. The oil production with replacement of glucose in MGYP with other Carbon sources was lower as compared to glucose. As seen in the Table 1, oil production in synthetic growth media containing different carbon sources suggest that the organism converts a variety of carbon sources, but more readily the hexose sugar glucose. Despite of this, the oil yields, oil content in the cells was found to be very less in the growth phase. Operating the fermenter in different modes like fed-batch and chemostat at varying dilution rates allowed for the increase in the cell densities up to $32.2 \mathrm{~g}$ of DCW/L (in chemostat mode, Table 2). The biomass productivity was thus increased considerably, but the oil content in the growth media didn't change notably. Thus, the optimization in media composition is also necessary along with optimization of fermenter parameters for increased growth and oil production.

\section{Role of $\mathrm{C} / \mathrm{N}$ ratio in microbial oil accumulation}

$\mathrm{C} / \mathrm{N}$ ratio has been reported to govern metabolisms like growth, organic acid production or conversion of excess carbon into lipids (triacylglycerols and sterol esters) [1,2]. By monitoring growth and $\mathrm{C} / \mathrm{N}$ ratio, carbon excess in the anabolism of oleaginous yeasts can be either oriented towards organic acids production or lipids production Beopoulos et al. [8]. Cell growth and lipid accumulation is affected by the excess of carbon and limited amount of nitrogen [1]. Yarrowia lipolytica culture involves two phases, first being the growth phase, which is slowed by nitrogen limitation followed by the lipid accumulation phase $[13,14]$. Conversion of sugars into lipids depends on the growth phase and the transition to the accumulation phase, which is influenced by the $\mathrm{C} / \mathrm{N}$ ratio. The total substrate-to-lipid conversion yield therefore depends on the initial $\mathrm{C} / \mathrm{N}$ ratio of the batch culture. Thus effect of medium composition on cell growth and lipid production was determined by varying the $\mathrm{C} / \mathrm{N}$ ratio in the medium.

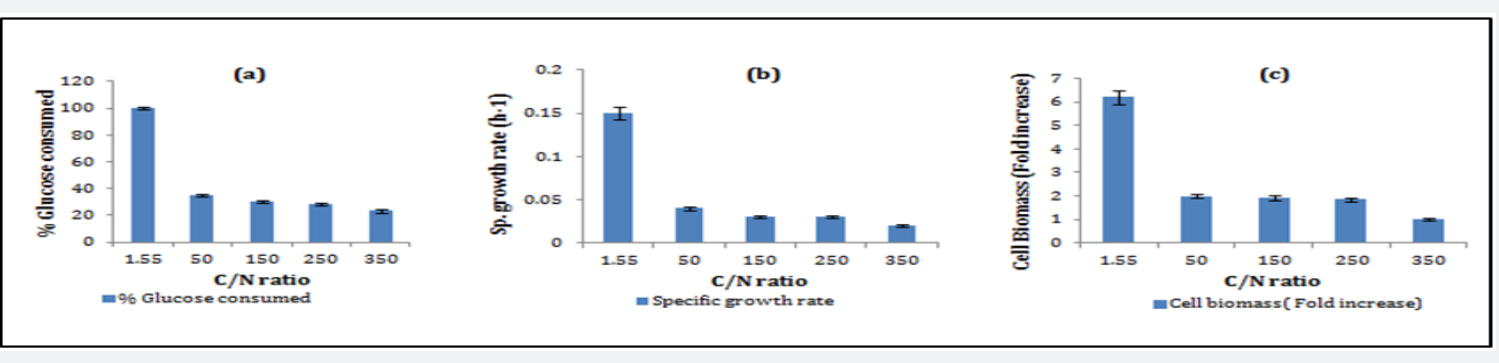

Figure 1: Effect of C/N ratio on Yarrowia lipolytica NCIM 3590, shows the effect of C/N ratio of the media components on (a) Glucose consumption (b) specific growth rate and (c) biomass growth of Yarrowia lipolytica NCIM 3590. 


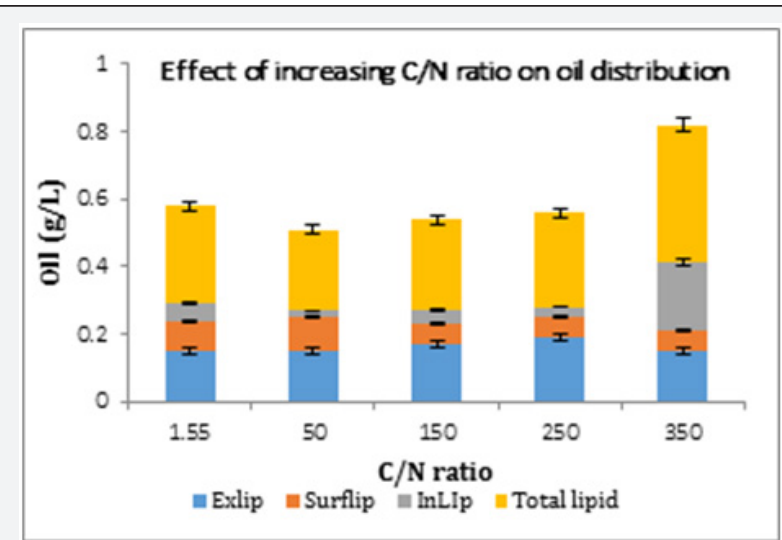

Figure 2: Effect of increasing $\mathrm{C} / \mathrm{N}$ ratio on oil distribution of Yarrowia lipolytica NCIM 3590, The distribution of the oil in the form of Extracellular lipid (Exlip), Surface lipid (Surf Lip), Intracellular lipid (In Lip) and Total Lipid with variation in $\mathrm{C} / \mathrm{N}$ ratio is shown with respect to oil titre $(\mathrm{g} / \mathrm{L})$.

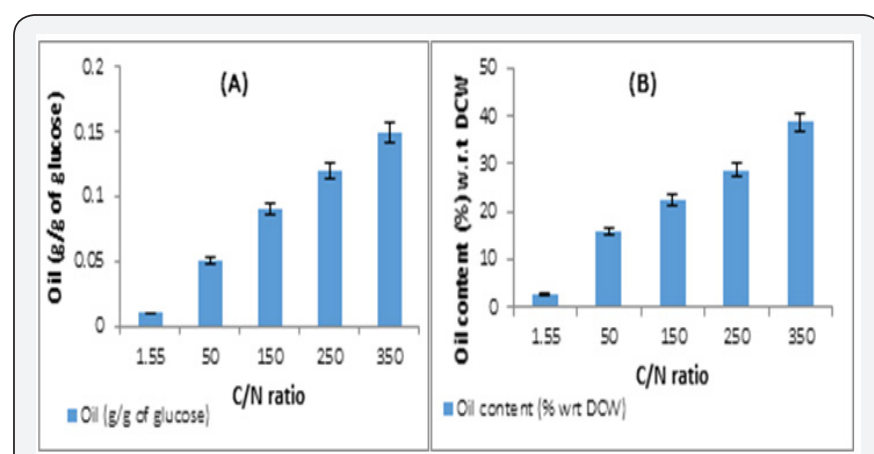

Figure 3: Effect of increasing $\mathrm{C} / \mathrm{N}$ ratio on oil produced per gram of glucose $(A)$ and on dry cell biomass (B),Variation in oil production with regards to the oil yield based on glucose consumption (oil g/g of glucose) and oil content (\%) wrt dry cell weight of biomass upon changing $\mathrm{C} / \mathrm{N}$ ratio.

The profiles in Figure 1 Prove that growth and biomass production of the oleaginous yeast was favored in the nitrogen rich medium, while the oil production in carbon rich medium
(Figure $2 \& 3$ ). Also, (Figure 1, $2 \& 3$ ), increasing the biomass production of the oleaginous cells in a nitrogen rich medium followed by sequential increase in the $\mathrm{C} / \mathrm{N}$ ratio for oil production is necessary [15].

\section{Increased biomass productivities with High cell density cultivation technique}

The cell biomass production of the oleaginous yeast strain (eg Yarrowia lipolytica NCIM 3590) was carried out in a 5L fermentor containing $1 \mathrm{~L}$ of MGYP media. Culturing was carried out in a batch mode, at $28{ }^{\circ} \mathrm{C}$, agitation of 200rpm and aeration of $1 \mathrm{vvm}$ for $48 \mathrm{hrs}$, till a cell density of $8 \mathrm{~g} / \mathrm{L}$ (1.6g DCW) was achieved. Later, the fermentor was operated in a chemostat mode at different dilution rates with higher concentration of Nitrogenous auxiliaries (Yeast extract and Peptone with 10 \& $20 \mathrm{~g} / \mathrm{L}$ concentrations) and sugar (glucose $100 \mathrm{~g} / \mathrm{L}$ ). The media was replenished continuously and the cells were retained using the Hollow fiber membrane system. Under this condition, maximum biomass productivity of $20 \mathrm{~g} / \mathrm{L} / \mathrm{h}$ was observed at a dilution rate of $0.12 \mathrm{~h}^{-1}$ (Table 3 ) with biomass yield of about $200 \mathrm{~g} / \mathrm{L}$. The cell biomass, thus obtained can be used for oil production6].

Table 3: Biomass productivities in chemostat mode with optimized growth media, Effect of dilution rates in chemostat mode with optimized proteinaceous media on the biomass productivities is depicted, $\mathrm{g} / \mathrm{L} / \mathrm{h}$ : grams per liter per hour.

\begin{tabular}{|c|c|}
\hline Dilution rate $\left(\mathbf{h}^{-\mathbf{1}}\right)$ & Productivity $(\mathrm{g} / \mathbf{L} / \mathbf{h})$ \\
\hline 0.01 & 1.06 \\
\hline 0.02 & 2.50 \\
\hline 0.05 & 8.48 \\
\hline 0.08 & 17.02 \\
\hline 0.10 & 18.57 \\
\hline 0.12 & 20.08 \\
\hline 0.14 & 19.14 \\
\hline
\end{tabular}

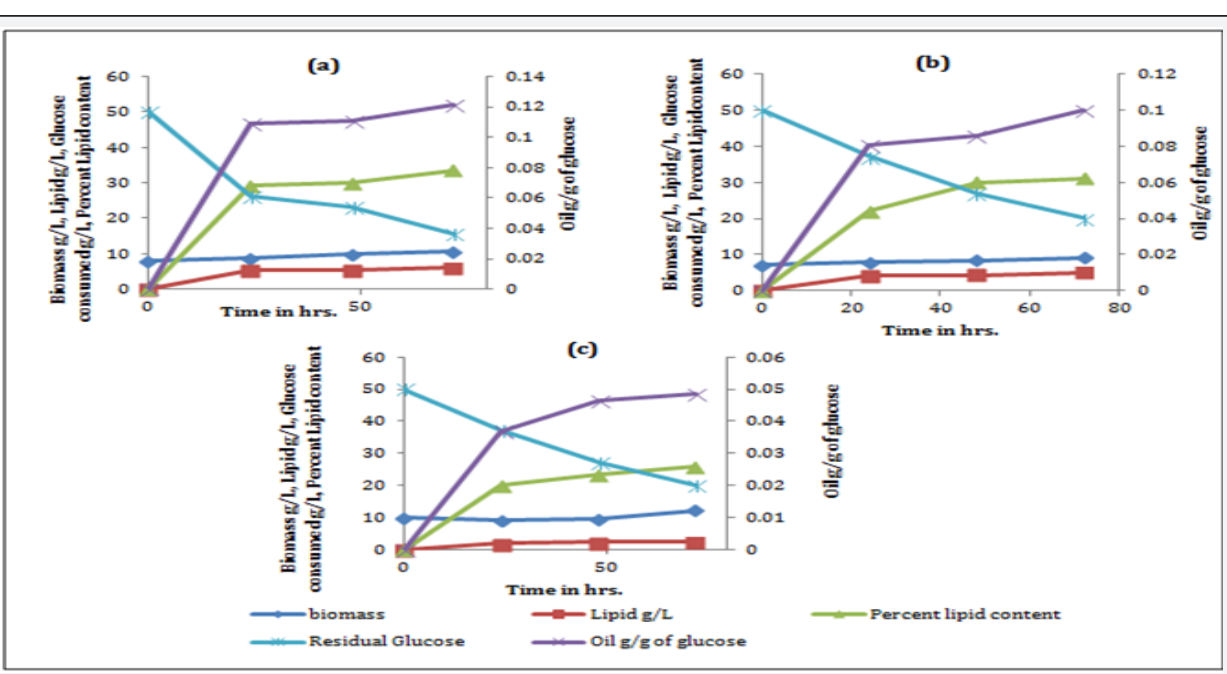

Figure 4: Oil production by Yarrowia lipolytica at different incubation temperatures (a) $20^{\circ} \mathrm{C}$ (b) $28^{\circ} \mathrm{C}$ (c) $37^{\circ} \mathrm{C}$, Oil production was carried out at different incubation temperatures. The effect of the incubation temperature on the growth of biomass, oil /Lipid titer, Glucose consumption and oil/Lipid content and oil yield based on glucose consumed is graphically represented. 
Oil production in sugar solutions without nitrogen ancillaries

Since oil production is favored in carbon rich media, cells of Yarrowia lipolytica NCIM 3590 were added in the synthetic glucose solutions of concentrations, ranging from 10 to $60 \mathrm{~g} / \mathrm{L}$. It was seen that highest content of oil was obtained with cells grown at high glucose concentration $(50 \mathrm{~g} / \mathrm{L})$. A maximum of $37 \%$ of oil with a yield of $0.15 \mathrm{~g} / \mathrm{g}$ of glucose was obtained with $50 \mathrm{~g} / \mathrm{L}$ of glucose as seen in Table 4 Further optimization carried out on the basis of temperature, with $50 \mathrm{~g} / \mathrm{L}$ sugar concentration showed that (Figure 4), higher oil production was seen obtained at $20^{\circ} \mathrm{C}$. Also, it can be noted from the figure that the growth of biomass was arrested in the glucose solution and all the carbon consumed uptaken by the organism was diverted towards lipid production. Also, it can be seen in Table 5 that increasing the cell inoculum density, there was increase in sugar consumption, oil content and oil titres. Thus, to increase the oil production titres, it is of utmost importance to have high cell densities into the oil production media [17].

Table 4: Oil production by Yarrowia lipolytica NCIM 3590 in different concentration of std. glucose solution, Oil production on the basis of oil/lipid content and oil yield with variation in the glucose concentration was studied, g/g: gram per gram; g/L: gram per liter; DCW: Dry cell weight.

\begin{tabular}{|c|c|c|c|c|c|}
\hline $\begin{array}{c}\text { Glucose } \\
\text { Concentration } \\
\text { (g/l) }\end{array}$ & 10 & 20 & 30 & 50 & 60 \\
\hline $\begin{array}{c}\text { Oil Content wrt } \\
\text { DCW (\%) }\end{array}$ & 26 & 29.30 & 33.17 & 37.07 & 34.32 \\
\hline $\begin{array}{c}\text { Oil Yield(g/g of } \\
\text { glucose) }\end{array}$ & 0.28 & 0.21 & 0.16 & 0.15 & 0.10 \\
\hline
\end{tabular}

Table 5: Oil production by Yarrowia lipolytica NCIM 3590 with increased cell density in $5 \%$ glucose solution, Variation in the cell inoculum densities for oil production in optimized $50 \mathrm{~g} / \mathrm{L}$ of glucose solution was studied, g/L: gram per liter; DCW: Dry cell weight.

\begin{tabular}{|c|c|c|c|c|c|c|c|}
\hline $\begin{array}{c}\text { Inoculum Cell } \\
\text { Density *Wet wt. } \\
\text { (g/L) }\end{array}$ & $\begin{array}{c}\text { DCW } \\
\text { Considering } \\
\text { Moisture } \\
\text { Content } \\
\text { (g/L) }\end{array}$ & $\begin{array}{c}\text { Sugar } \\
\text { (Glucose) } \\
\text { Concentration } \\
\text { (g/L) }\end{array}$ & $\begin{array}{c}\text { Sugar } \\
\text { consumed } \\
\text { after 72 hrs } \\
\text { (g/L) }\end{array}$ & $\begin{array}{c}\text { Sugar } \\
\text { Consumption(\%) }\end{array}$ & $\begin{array}{c}\text { Oil Yield } \\
\text { (g/g of Sugar } \\
\text { consumed) }\end{array}$ & Oil Content(\%) & $\begin{array}{c}\text { 0il Titer } \\
\text { (g/L) }\end{array}$ \\
\hline 30 & 6 & 46 & 12.4 & 26.9 & 0.17 & 36.2 & 2.2 \\
\hline 50 & 10 & 50.1 & 25.75 & 48.6 & 0.15 & 37.07 & 3.7 \\
\hline 128 & 12.8 & 48 & 36 & 75 & 0.13 & 37.5 & 4.8 \\
\hline
\end{tabular}

Similar set of experiments were performed replacing glucose with a $\mathrm{C}-5$ sugar solution, containing xylose as the sole source of carbon. Assimilation of C-5 carbon source into lipids was shown by Yarrowia. Thus, the Yarrowia lipolytica NCIM 3590 was used for oil production using different sugars, i.e hexoses

and pentoses. Also, it can be noted that the sugar consumption in xylose was lesser as compared to glucose. But, the trend of increased sugar uptake, oil titres and oil content in cells with increase in the inoculum density remained valid in this case as well [18] (Table 6).

Table 6: Oil production by Yarrowia lipolytica NCIM 3590 with increased cell density in $5 \%$ xylose solution, Effect of variation in the cell inoculum densities on oil production with xylose solution of $50 \mathrm{~g} / \mathrm{L}$ concentration was studied with optimized parameters of the glucose system, $\mathrm{g} / \mathrm{g}$ : gram per gram; g/L: gram per liter; DCW: Dry cell weight.

\begin{tabular}{|c|c|c|c|c|c|c|c|}
\hline $\begin{array}{c}\text { Inoculum Cell } \\
\text { Density Wet } \\
\text { wt. (g/L) }\end{array}$ & $\begin{array}{c}\text { DCW } \\
\text { Considering } \\
\text { Moisture } \\
\text { Content (g/L) }\end{array}$ & $\begin{array}{c}\text { Sugar (Xylose) } \\
\text { Concentration } \\
\text { (g/L) }\end{array}$ & $\begin{array}{c}\text { Sugar } \\
\text { Consumed } \\
\text { after 72 hrs } \\
\text { (g/L) }\end{array}$ & $\begin{array}{c}\text { Sugar } \\
\text { Consumption(\%) }\end{array}$ & $\begin{array}{c}\text { Oil Yield } \\
\text { (g/g of Sugar } \\
\text { consumed) }\end{array}$ & $\begin{array}{c}\text { Oil Content(\%) } \\
\text { Oil Titer } \\
\text { (g/L) }\end{array}$ \\
\hline 12.29 & 2.47 & 31.83 & 0.52 & 0.98 & 0.32 & 6.90 & 0.17 \\
\hline 50 & 10 & 44.82 & 4.19 & 9.06 & 0.24 & 10.23 & 1.02 \\
\hline
\end{tabular}

Thus, the two stage approach of High cell density cultivation of oleaginous yeast cells in first stage followed by oil production in sugar solutions without nitrogenous ancillaries can provide for a better alternative for increasing the oil production in contrast to the conventional single stage process.

\section{Two-stage approach for microbial oil production}

As seen earlier, the $\mathrm{C} / \mathrm{N}$ ratio of the media plays a crucial role in the growth and oil production by oleaginous yeast strains. The two stages thus need to be carried out separately so as to enhance either growth or oil production and thus later make use of the better of the two phases to combine and increase the productivity of the overall process. The high cell density cultivation with optimized growth media in a chemostat can yield biomass productivities of $20 \mathrm{~g} / \mathrm{L} / \mathrm{h}$, yielding cell densities of about $200 \mathrm{~g}$ wet weight (i.e around $40 \mathrm{~g}$ DCW). This, when coupled with transfer of the cell biomass into oil production media with higher sugar/ C-Source concentrations can help increase the oil production in terms of the oil titers and thereby the productivity of the production process. As seen Table 5, when $128 \mathrm{~g} / \mathrm{L}$ cell biomass was used for oil production in a $48 \mathrm{~g} / \mathrm{L}$ of glucose solution devoid of nitrogen source, the sugar assimilation increased with increase in the oil production in the form of oil content and oil titre. The results were valid with pentose sugar as well [19].

Earlier work on the separation of the growth and oil production phases in different oleaginous organisms [10] 
differs from the current methodology, wherein the present work adopts a chemostat with cell retention for growth followed by oil production in batch mode. This approach provides the organism with an adequate residence time for growth and oil production in the respective phases, while it deals with the stress conditions prevalent in the fermenter. Further, it also provides for maintaining the cell biomass in a particular phase of growth, thus allowing the metabolic activities, pertaining to that phase, to be carried out for a longer duration of time.

\section{Lipid profiles of microbial oil produced by Yarrowia lipolytica}

The microbial oil produced by Yarrowia lipolytica NCIM 3590 using glucose and xylose as substrate was analyzed for its lipid profile using GC-MS for fatty acid compositional analysis and HPLC-ELSD for glyceride composition analysis. It was found that the oil produced was majorly in the form of triglyceride with very less content of Free Fatty Acid (Table 7), Thus making it amenable to be used as an edible source along with its potential to be used in bio fuel. The incubation temperature plays an important role in the lipid profile of the microbial oil, as seen in Table 8. Thus, a desired composition can be obtained by adjusting the incubation Table 9: Composition of glycerides obtained from Yarrowia lipolytica NCIM 3590, Compositional analysis of glycerides for oil produced using different sugars was studied with HPLC -ELSD system.

\begin{tabular}{|c|c|c|c|c|c|}
\hline Sugar & ECN 18-24 & ECN 24-30 & ECN 30-36 & ECN 36-42 & $1.27 \%$ \\
\hline Glucose & $64.08 \%$ & 23.50 & $2.67 \%$ & $7.69 \%$ & $16.66 \%$ \\
\hline Xylose & $20.17 \%$ & $26.42 \%$ & $21.38 \%$ & $9.66 \%$ \\
\hline
\end{tabular}

\section{Conclusion}

The microbial oil production process using oleaginous yeast can be made attractive if the oil titers, yields and productivities are increased. This increase can be obtained if the growth phase does not coincide with the synthesis of the oil. For this purpose, studying the variations in the metabolic status of the microorganisms due to changes in the growth conditions becomes crucial. Following these changes in a two-stage approach is easier where in high cell density of oleaginous yeast cells is achieved, by providing proteinaceous nitrogen enriched medium followed by oil accumulation in the later phase in a medium containing carbon source. This also allows arresting the high cell biomass in stationary phase for a longer duration of time, thus driving the oil production process towards increased oil productivities.

\section{Acknowledgement}

This work was supported by DBT-ICT-Centre for Energy Biosciences, Institute of Chemical Technology Mumbai, and India.

\section{References}

1. Ratledge C (2004) Fatty acid biosynthesis in microorganisms being used for single cell oil production. Biochimie 86(11): 807-815.

2. Wynn JP, Ratledge C (2005) Microbial production of oils and fats, in Food Biotechnology. In: K Shetty, G Paliyath, A Pometto, RE Levin temperature. Also, further it can be noted that the carbon source or the nature of sugar (i.e. hexose or pentose) has an effect in packing the lipids in the form of glycerides of particular form, length and saturation (Table 9) [20,21].

Table 7: Free Fatty Acid content in the oil produced by Yarrowia lipolytica, The Free fatty acid content in the microbial oil produced using different sugars was estimated by proximate titrimetric analysis,FFA: Free fatty acid.

\begin{tabular}{|c|c|c|}
\hline \multirow{2}{*}{$\begin{array}{c}\text { Yarrowia lipolytica } \\
\text { Strain No. }\end{array}$} & \multicolumn{2}{|c|}{ FFA Content in Oil (\%) } \\
\cline { 2 - 3 } & Glucose & Xylose \\
\hline NCIM 3590 & 4.47 & 1.02 \\
\hline
\end{tabular}

Table 8: Fatty acid composition of oil accumulated by Yarrowia lipolytica NCIM 3590, Effect of incubation temperature on the fatty acid profile of the oil produced was studied using FAME analysis by GC-MS after derivatization in to fatty acid methyl esters, ECN: Equivalent carbon number.

\begin{tabular}{|c|c|c|c|}
\hline \multirow{2}{*}{$\begin{array}{c}\text { ncubation } \\
\text { temperature }\end{array}$} & \multicolumn{3}{|c|}{ Fatty Acid Composition (\%) } \\
\cline { 2 - 4 } & $\mathbf{C 1 6}$ & $\mathbf{C 1 8}$ & $\mathbf{C 1 8 : 1}$ \\
\hline $20^{\circ} \mathrm{C}$ & 53 & 1.73 & 14 \\
\hline $28^{\circ} \mathrm{C}$ & 21.80 & 3.95 & 74.23 \\
\hline $37^{\circ} \mathrm{C}$ & 32.83 & 4.34 & 62.88 \\
\hline
\end{tabular}

(Eds.), Food Science and Technology, $2^{\text {nd }}($ edn), FL: CRC Press, USA, pp. 443-472.

3. Li Y, Horsman M, Wu N, Lan CQ, Dubois-Calero N, et al. (2008) Biofuels from microalgae. Biotechnol Prog 24(4): 815-820.

4. Bellou S, Triantaphyllidou IE, Aggeli D, Elazzazy AM, Baeshen MN, et al. (2016) Microbial oils as food additives: recent approaches for improving microbial oil production and its polyunsaturated fatty acid content. Current Opinions in Biotechnology 37: 24-35.

5. Ward OP, Singh A (2005b) Omega-3/6 fatty acids: alternative sources of production. Process Biochem 40(12): 3627-3652.

6. Li Q, Du W, Liu D (2008) Perspectives of microbial oils for biodiesel production. Appl Microbiol Biotechnol 80(5): 749-756.

7. Ageitos JM, Vallejo JA, Veiga-Crespo P, Villa TG (2011) Oily yeasts as oleaginous cell factories. Applied Microbiology and Biotechnology 90(4): 1219-1227.

8. Beopoulos A, Cescut J, Haddouche R, Uribelarrea JL, Molina-Jouve C, et al. (2009) Yarrowia lipolytica as a model for bio-oil production. Progress in Lipid research 48(6): 375-387.

9. Blazeck J, Hill A, Liu L, Knight R, Miller J, et al. (2014) Harnessing Yarrowia lipolytica lipogenesis to create a platform for lipid and biofuel production. Nature Communications 5: 3131.

10. Hall MJ, Ratledge C (1977) Lipid Accumulation in an Oleaginous Yeast (Candida 107) Growing on Glucose under Various Conditions in a Oneand Two-Stage Continuous Culture. Appl Environ Microbiol 33(3): 577-584.

11. Yao L, Lee SL, Wang T, Gerde JA (2013) Comparison of lipid extraction from microalgae and soybeans with aqueous isopropanol. J Am Oil Chem Soc 90(4): 571-578. 
12. Shantha NC, Napolitano GE (1992) Gas chromatography of fatty acids. Journal of Chromatography A 624(1-2): 37-51.

13. Briffaud J, Engasser J (1979) Citric acid production from glucose Growth and excretion kinetics in a stirred fermentor. Biotechnology and Bioengineering 21(11): 2083-2092.

14. Engasser JM, Hisland P (1979) Diffusional effects on the heterogeneous kinetics of two-substrate enzymic reactions. J Theor Biol 77(4): 427440

15. Enshaeieh M, Abdoli A, Nahvi I, Madani M (2012) Bioconversion of different carbon sources into microbial oil and biodiesel using oleaginous yeasts. Journal of biology and today's world, 1(2): 42-47.

16. Fakas S, Papanikolaou S, Batsos A, Galiotou-Panayotou M, Mallouchos A, et al. (2008) Evaluating renewable carbon sources as substrates for single cell oil production by Cunninghamella echinulata and Mortierella isabellina. Biomass and Bioenergy 33(4): 573-580.
17. Fickers P, Benetti PH, Wache Y, Marty A, Mauersberger S, et al. (2005) Hydrophobic substrate utilisation by the yeast Yarrowia lipolytica, and its potential applications. FEMS Yeast Research 5(6-7): 527-543.

18. Liu HH, Ji XJ, Huang H (2015) Biotechnological applications of Yarrowia lipolytica: Past, present and future. Biotechnology Advances 33(8): 1522-1546.

19. Papone T, Kookkhunthod S, Paungbut M, Leesing R (2016) Producing of Microbial Oil by Mixed Culture of Microalgae and Oleaginous Yeast Using Sugarcane Molasses as Carbon Substrate. Journal of Clean Energy Technologies 4(4): 253-256.

20. Xu J, Du W, Zhao X, Zhang G, Liu D, et al. (2012) Microbial oil production from various carbon sources and its use for biodiesel preparation. Biofuels, Bioproducts and Bio refining 7(1): 65-77.

21. Li Y, Zhao Z, Bai F (2007) High-density cultivation of oleaginous yeast Rhodosporidium toruloides Y4 in fed-batch culture. Enzyme and Microbial Technology 41(3): 312-317.

\section{Your next submission with Juniper Publishers will reach you the below assets}

Commons Attribution 4.0 Licens

DOI: 10.19080/AIBM.2017.05.555652 